\title{
Water Management and Water Relations of Horticultural Crops: Introduction to the Colloquium
}

\author{
Larry R. Parsons ${ }^{1}$ \\ University of Florida, Institute of Food and Agricultural Sciences, Citrus Research and Education Center, Lake \\ Alfred, FL 33850-2299
}

Irrigation was a major factor in the settlement of the western United States. Shortly after the Mormon pioneers settled in Utah, they began diverting water from mountain streams to irrigate the land (Reisner, 1986). Because of its sparse rainfall, the land west of long. $100^{\circ} \mathrm{W}$ was once called the Great American Desert. State and federal water policies were devised to provide low-cost water to encourage settlers

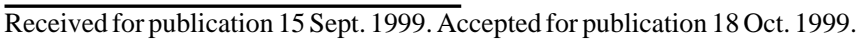
Florida Agricultural Experiment Station Journal Series No. R-07064. The cost of publishing this paper was defrayed in part by the payment of page charges. Under postal regulations, this paper therefore must be hereby marked advertisement solely to indicate this fact.

'Professor of Horticulture, lrp@lal.ufl.edu. to move west. Irrigation was viewed as serving the national interest by encouraging western settlement and allowing the "desert to bloom." Without irrigation, the agricultural productivity of the western United States would be a fraction of what it is today. In addition to dramatically increasing crop production in arid regions, a major advantage of irrigation is the stabilization of crop production and prices from year to year. Irrigation helps smooth out the cycles between feast and famine.

Massive federal water projects that dammed hundreds of rivers helped subsidize agriculture in western America. While these projects were once hailed as a boon for the entire United States, the attitude toward them and irrigation in general is now changing. Salinization of the soil and return flows from agricultural lands that degrade water 


\section{Colloquium}

quality are potential negative aspects of long-term irrigation. As urban populations grow and compete with agriculture for limited water resources, the benefit to the nation of subsidized water for agriculture has been questioned by some. Both the costs and the demand for water are rising. Parks, recreational areas, and golf courses are now competing for water that formerly went to lower value crops such as alfalfa. Water for wetlands and fish and wildlife habitats is now considered as important as water for agriculture.

In the 1930 s through 1960 s, when water was relatively inexpensive, neither irrigation efficiency nor water management was considered to be important. Flood, furrow, or high-volume sprinkler irrigation systems were commonly used. Overirrigation was considered to be cheap insurance to guarantee top yields. However, overirrigation, particularly with slightly salty water, helped salt up some regions and led to agricultural drainage problems. An example of an agricultural drainage project that created negative environmental impacts is the Kesterson National Wildlife Refuge in California (Clemings, 1996).

Population growth has brought about an increased demand for fresh water in many parts of the world. Agriculture has been one of the primary users of water. One example where agricultural pumping has had a major impact is the Ogallala aquifer, which provides groundwater for parts of Texas, Kansas, Colorado, Oklahoma, New Mexico, and Nebraska. The Ogallala is one of the world's largest discrete aquifers, but is becoming one the most rapidly disappearing aquifers in the world (Reisner, 1986). Water use at this high rate has been likened to a mining operation, and the sustainability of this usage has been questioned (Postel, 1993).

Arid regions are not alone in suffering water shortages. One of the largest desalination plants in the United States will be built near Tampa, Fla., within the next decade. This region, which commonly receives over $1200 \mathrm{~mm}$ of rain per year, needs even more fresh water for its growing population.

Population demand has led to a number of water development projects worldwide. While these have benefited many people, Postel (1992) suggests that "masking scarcity is the principal aim of water development." She argues "A new water era has begun. In contrast to earlier decades of unfettered damming, drilling, and diverting to gain ever greater control over water, the next generation will be marked by limits and constraints-political, economic, and ecological."

The price and availability of water will continue to be primary factors influencing the extent of irrigation in the western United States. Availability and regulatory restrictions on water are becoming more important in the eastern and southern United States as well. The Committee on the Future of Irrigation (1996) has predicted that the volume of water allocated to agricultural irrigation will decline. Turf, urban landscape, and golf course irrigation will expand as urbanization increases. There will be continued pressure to deal with environmental problems associated with agricultural irrigation. Improved irrigation management and scheduling and the use of microirrigation will become more important as water scarcities increase. Treated, reclaimed, municipal wastewater has been used for crop irrigation for decades in certain arid regions (Feigin et al., 1991; Pettygrove and
Asano, 1985) and its use is rising in several states. Once considered a disposal problem, wastewater that is treated to meet reclaimed water standards is now a viable source of irrigation water (Parsons and Wheaton, 1996). To gain more flexibility in allocating water, methods to market it or facilitate its voluntary transfer are also being considered (Postel, 1993).

Horticultural crops usually have higher market value than traditional agricultural crops. Hence, improved water-saving technologies have been focused on certain horticultural crops. Water scarcity, economic consideration, and regulatory influences have led to drip irrigation of a number of vegetable crops in the southern and eastern United States. Fruit trees have also been successfully irrigated with microsprinklers (Hochmuth et al., 1993).

This colloquium deals with a number of aspects of water, ranging from cellular water relations to field-scale desert irrigation. Topics include discussions on water conservation in urban and field agricultural situations, responses of plants to incomplete root zone wetting or deficit irrigation, and the importance of irrigation in humid as well as arid climates. Other topics include the economic and environmental consequences of desert irrigation, the use of lower quality water sources for irrigation, effects of water stress on vegetative and fruit growth, and growth responses of leaves and roots to changes in water status.

Irrigation and water management will continue to be important components in both agricultural production and the urban landscape. Water scarcities and increasing demand for water will have major political and economic impacts throughout the world. Because of their higher value and more intense cultural practices, horticultural crops are better suited for adaptation to improved water-saving technologies than are many agronomic crops. Water is one of the most important plant growth regulators, and how well we manage it will influence our future well-being.

\section{Literature Cited}

Clemings, R. 1996. Mirage-The false promise of desert agriculture. Sierra Club Books, San Francisco.

Committee on the Future of Irrigation in the Face of Competing Demands. 1996. A new era for irrigation. Water Sci. and Technol. Board. Natl. Res. Council. Natl. Academy Press, Washington, D.C.

Feigin, A., I. Ravina, and J. Shalhevet. 1991. Irrigation with treated sewage effluent. Springer-Verlag, Berlin.

Hochmuth, G.J., S.J. Locascio, T.E. Crocker, C.D. Stanley, G.A. Clark, and L.R. Parsons. 1993. Impact of microirrigation on Florida horticulture. HortTechnology 3:223-229.

Parsons, L.R. and T.A. Wheaton. 1996. Florida citrus irrigation with municipal reclaimed water. Proc. Intl. Soc. Citricult. 692-695.

Pettygrove, G.S. and T. Asano (eds.). 1985. Irrigation with reclaimed municipal wastewater-A guidance manual. Lewis Publishers, Chelsea, Mich.

Postel, S. 1992. Last oasis-Facing water scarcity. W.W. Norton, New York.

Postel, S. 1993. Water and agriculture, p. 56-64. In: P.H. Gleick (ed.). Water in crisis: A guide to the world's fresh water resources. Oxford Univ. Press, Oxford.

Reisner, M. 1986. Cadillac desert. Viking Penguin, New York. 